NOTE

\title{
Increased blooms of a dinoflagellate in the NW Atlantic
}

\author{
D. G. Johns ${ }^{1, *}$, M. Edwards ${ }^{1}$, A. Richardson ${ }^{1}$, J. I. Spicer ${ }^{2}$ \\ ${ }^{1}$ Sir Alister Hardy Foundation for Ocean Science (SAHFOS), The Laboratory, Citadel Hill, The Hoe, Plymouth, \\ PL1 2PB, UK \\ ${ }^{2}$ School of Biological Sciences, University of Plymouth, Plymouth PL4 8AA, UK
}

\begin{abstract}
Sampling by the Continuous Plankton Recorder (CPR) over the NW Atlantic from 1960 to 2000 has enabled long-term studies of the larger components of the phytoplankton community, highlighting various changes, particularly during the 1990s. Analysis of an index of phytoplankton biomass, the Phytoplankton Colour Index (PCI) has revealed an increase over the past decade, most marked during the winter (December to February) months. Examination of the structure of the community using multiple linear-regression models indicates that the winter phytoplankton community composition has changed markedly in the 1990s compared to the 1960s. One phytoplankter, the dinoflagellate Ceratium arcticum (Cleve), has undergone dramatic changes in abundance during this period, with pronounced large winter blooms and decreased autumnal levels, and its contribution to the Phytoplankton Colour index values has increased significantly. Other dominant species in the phytoplankton community, both diatoms and dinoflagellates, did not show the same variations over the examined time period. It is suggested that the response of $C$. arcticum is probably a result of previously reported changes in stratification in the NW Atlantic, due to dynamic hydro-climatic (freshening and cooling) events.
\end{abstract}

KEY WORDS: Phytoplankton · Long-term changes · Blooms · NW Atlantic · Ceratium arcticum • Continuous Plankton Recorder

\section{INTRODUCTION}

Phytoplankton community structure in the NW Atlantic has received less attention than the higher trophic levels such as fish (Nakashima 1994, Carscadden et al. 2001). Any fundamental changes, however, in the abundance or species composition of autotrophs may impact higher trophic levels. This is especially true in a hydrographically complex area such as the NW Atlantic, with a series of thermohaline and winddriven currents forming cold-warm water, surfacedeepwater interactions (Pickart et al. 1999) and supporting historically rich fisheries in the shelf area (i.e. Grand Banks).
Over the last decade, the well-documented decline of the ground fisheries of the Grand Banks has been attributed to overfishing (Hutchings 1996) as well as environmental pressures (Morgan et al. 2002). The presumption that the cod collapse was solely due to overfishing does not take into account the changes in capelin, a major food source for cod in the area (Lilly 1994), and other environmental factors. During the 1990s, many aspects of capelin biology and distribution changed (DFO 2000a), as well as increases in abundance and extension of distribution of the arctic boreal calanoid Calanus hyperboreus (Johns et al. 2001). Changes that may have occurred in phytoplankton abundance and community composition need to be described. 
The composition of the larger components of the phytoplankton community of the North Atlantic is commonly thought to follow an annual succession that begins with the spring diatom bloom and leads to the dominance of flagellates and dinoflagellates in summer. Diatom blooms are normally initiated by the shallowing of the mixed layer and an increase in light intensity in spring (Backhaus et al. 1999). Dinoflagellate communities are associated with post-spring bloom conditions, when surface waters are limited by the amount of nutrients remaining after the initial diatom bloom (Williams \& Lindley 1980). In addition, blooms in winter can occur as a response to halostratification following freshwater run-off (Labry et al. 2001).

The Continuous Plankton Recorder (CPR) survey has sampled the phytoplankton and zooplankton community of the NW Atlantic for almost 40 yr (for full methodology see Warner \& Hays 1994). Due to the mesh size of the CPR silks, larger phytoplankton species are sampled more quantitatively than smaller species, although small phytoplankton down to $10 \mu \mathrm{m}$ such as Scripsiella and Prorocentrum spp. are captured. Robinson (1970) found that the proportion of the population that is retained by the CPR silks reflects the major changes in abundance, distribution and specific composition of phytoplankton. As well as species information, the CPR survey has an index of chlorophyll a (chl a), the Phytoplankton Colour Index (PCI, Hays \& Lindley 1994). Over the last decade the PCI on the Scotian Shelf ecosystem has increased over all seasons, along with an extension of the productive period during winter (DFO 2000b, Sameoto 2001). It is not known

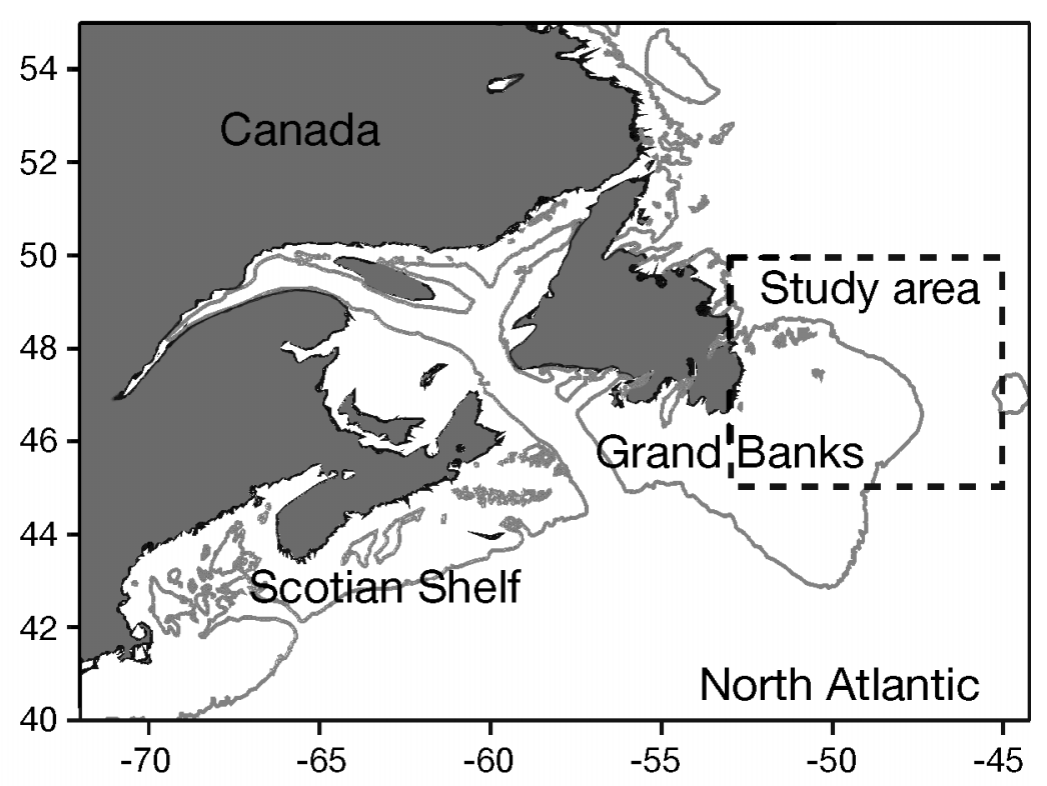

Fig. 1. Map of NW Atlantic. (- - -) indicates study area whether this increase is typical of other areas in the NW Atlantic, or whether all members of the phytoplankton community are contributing to the changes observed. In this study, the area of investigation is the neighbouring Grand Banks and northeast Newfoundland Shelf $\left(53-45^{\circ} \mathrm{W}, 45-50^{\circ} \mathrm{N}\right.$, Fig. 1), an area of considerable commercial fisheries importance and consistent CPR sampling $(\mathrm{n}=5574)$. Here we aim to show that the changes in PCI, particularly during the winter months, are linked to hydro-climatic variables, and that these may be propagating to higher trophic levels.

\section{MATERIALS AND METHODS}

The CPR survey provides a unique long-term dataset of plankton abundance in the North Atlantic and North Sea, using 'ships of opportunity' on regular routes to tow the CPR at about $10 \mathrm{~m}$ depth. Each sample represents $18 \mathrm{~km}$ of tow and approximately $3 \mathrm{~m}^{3}$ of filtered seawater (John et al. 2002). The CPR has been deployed in the study area on an approximately monthly basis from 1960 to 2000, although there was reduced sampling from 1978 to 1991, so this period was omitted from data analysis. Phytoplankton species examined are enumerated as the number of fields of view they were present in for each sample (maximum 20). This number is then extrapolated to a numerical abundance using the method described in Robinson \& Hiby (1978). In addition to the identification of phytoplankton abundance on each sample, the PCI is recorded as 1 of 4 categories of colour intensity. This gives an estimate of the density of phytoplankton on the CPR silk (Hays \& Lindley 1994).

The most abundant phytoplankton species in the study area were identified (those occurring in $>1 \%$ of samples). Long-term seasonal trends of the most abundant dinoflagellate and diatom species were examined using monthly means. Missing values were interpolated according to Colebrook (1975) if there were sufficient data available (more than 7 mo sampled in a given year). Due to the paucity of sampling during 1960 and 1961, these periods did not meet the criterion for inclusion and were therefore omitted from seasonal analysis, leaving the periods 1962 to 1978 and 1991 to 2000. To identify phytoplankton species that contributed to the PCIs in each of these periods, multiple linear-regression models were constructed. A forward-backward step- 
wise model-fitting procedure was used based on the Akaike's Information Criterion statistic (Venables \& Ripley 2002).

\section{RESULTS AND DISCUSSION}

PCI values have increased over the time period, and are most pronounced during the winter months (December to February, Fig. 2), similar to that noted in the southwest on the Scotian Shelf (Sameoto 2001). The contribution that phytoplankton taxa make towards this increase in PCI during winter for the peri-

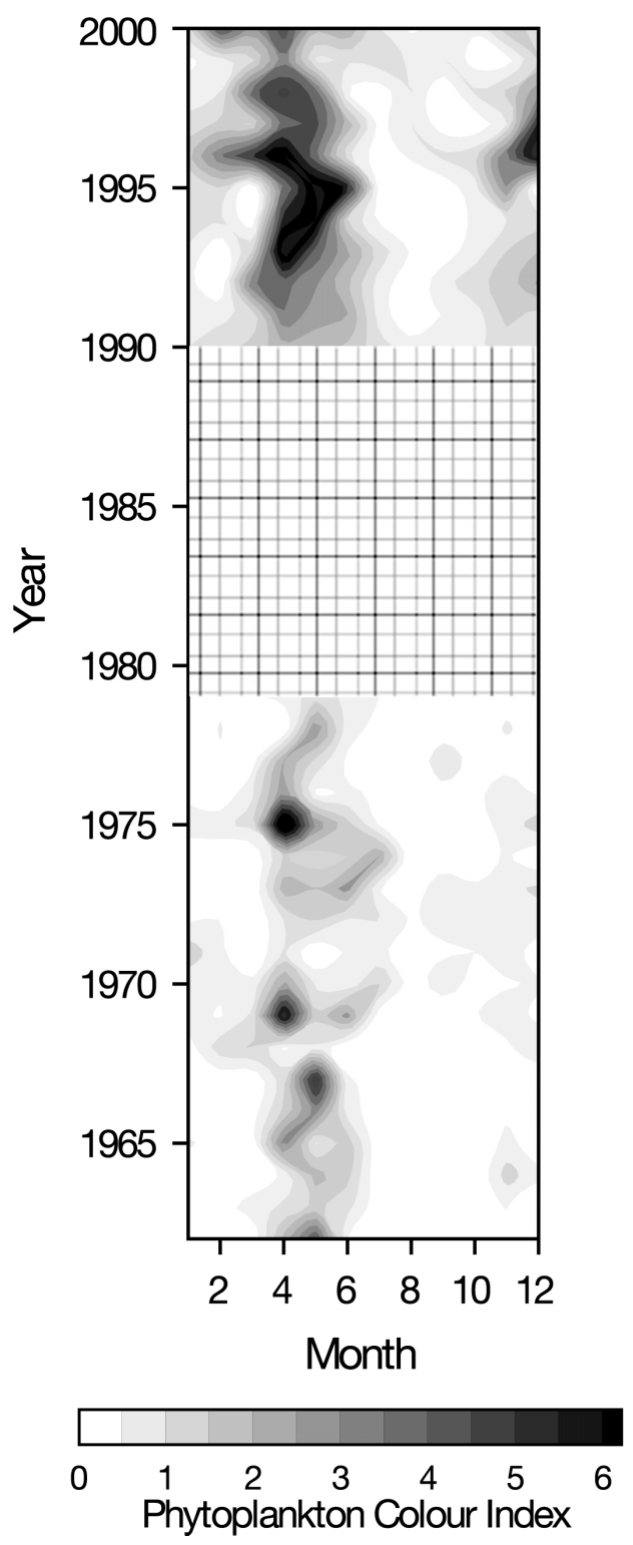

Fig. 2. Long-term seasonal contour plot of Phytoplankton Colour Index (PCI) ods 1962 to 1979 and 1991 to 2000 is shown in Table 1. Note that all slopes were positive, indicating that (as expected) increases in abundance of each taxa increased the greenness of the silk. Species are ranked in order from the most important contributors (highest $\mathrm{r}^{2}$ values) to the least. Viewing both time periods together, it is apparent that significant changes in the phytoplankton community have taken place. The actual number of contributing species to winter PCI has altered, from 14 in the 1962 to 1979 period, to only 9 during the 1991 to 2000 period, indicating that the number of species dominating the phytoplankton community has decreased. In addition, the rank importance of various taxa to PCI values was different in the 2 periods. This was typified by the arctic-boreal dinoflagellate Ceratium arcticum (Lebour 1925, Smayda 1958, Okolodkov \& Dodge 1996), which did not contribute to the winter PCI in 1962 to 1979 , but was the second most important taxon in the 1991 to 2000 period (Fig. 3). This recent strong dependence of PCI on $C$. arcticum abundance is highlighted by the high correlation in the second period $\left(\mathrm{r}^{2}=0.78, \mathrm{p}<0.01, \mathrm{n}=9\right)$, coupled with the absence of a relationship in the first period. No other dinoflagellate or diatom species were

Table 1. Final multiple-regression model for predicting the Phytoplankton Colour Index (PCI) from a suite of 23 phytoplankton taxa for (a) 1962 to $1978\left(\mathrm{r}^{2}=53.0 \%\right)$ and (b) 1991 to $2000\left(\mathrm{r}^{2}=51.8 \%\right)$. Phytoplankton taxa are ordered in terms of their relative importance for predicting Phytoplankton Colour $\left(\mathrm{r}^{2}\right)$

\begin{tabular}{|lrrrr|}
\hline Taxon & Slope & \multicolumn{1}{c|}{$\mathrm{r}^{2}$} & $\mathrm{p}$ \\
\hline (a) 1962 to 1978 & & & \\
Thalassiosira spp. & $5.7 \times 10^{-6}$ & 36.1 & $<0.0001$ \\
Phaeoceros spp. & $6.4 \times 10^{-6}$ & 10.7 & $<0.0001$ \\
Thalassiothrix longissima & $4.6 \times 10^{-6}$ & 2.9 & $<0.0001$ \\
Coscinodiscus spp. & $1.1 \times 10^{-5}$ & 0.9 & $<0.0001$ \\
Rhizosolenia hebetata semispina & $5.8 \times 10^{-6}$ & 0.7 & $<0.0001$ \\
Hyalochaete spp. & $1.8 \times 10^{-6}$ & 0.3 & $<0.0001$ \\
Ceratium macrocerus & $2.6 \times 10^{-5}$ & 0.3 & $<0.0001$ \\
Rhizosolenia styliformis & $7.8 \times 10^{-6}$ & 0.3 & $<0.0001$ \\
Ceratium fusus & $2.6 \times 10^{-6}$ & 0.2 & $<0.0001$ \\
Thalassionema nitzschiodes & $3.9 \times 10^{-6}$ & 0.1 & 0.0004 \\
Fragillaria spp. & $3.5 \times 10^{-6}$ & 0.1 & 0.0007 \\
Ceratium tripos & $7.7 \times 10^{-6}$ & 0.1 & 0.0020 \\
Corethron criophilum & $5.1 \times 10^{-5}$ & 0.1 & 0.0103 \\
Pseudo-nitzschia spp. & $3.8 \times 10^{-6}$ & 0.1 & 0.0152 \\
(b) 1991 to 2000 & & & \\
Thalassiosira spp. & $5.2 \times 10^{-6}$ & 26.3 & $<0.0001$ \\
Ceratium arcticum & $6.5 \times 10^{-6}$ & 12.1 & $<0.0001$ \\
Thalassiothrix longissima & $6.1 \times 10^{-6}$ & 7.1 & $<0.0001$ \\
Phaeoceros spp. & $4.2 \times 10^{-6}$ & 3.0 & $<0.0001$ \\
Thalassionema nitzschiodes & $1.9 \times 10^{-5}$ & 1.3 & $<0.0001$ \\
Corethron criophilum & $3.9 \times 10^{-5}$ & 0.8 & $<0.0001$ \\
Pseudo-nitzschia spp. & $3.3 \times 10^{-5}$ & 0.4 & 0.0003 \\
Ceratium horridum & $1.7 \times 10^{-5}$ & 0.4 & 0.0006 \\
Coscinodiscus spp. & $1.3 \times 10^{-5}$ & 0.3 & 0.0035 \\
& & & \\
\hline
\end{tabular}




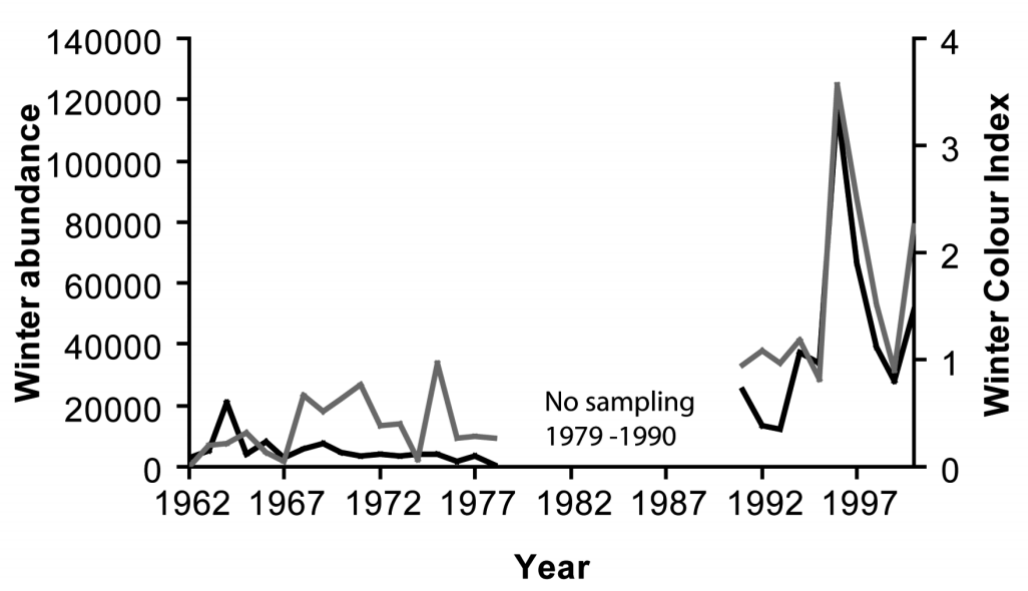

Fig. 3. Ceratium arcticum. Long-term winter abundance (black) and longterm winter Phytoplankton Colour values (grey). Density of C. arcticum = mean cell count per sample $\left(\sim 3 \mathrm{~m}^{3}\right)$

correlated with changes in $\mathrm{PCI}$; and none have exhibited similar seasonal changes as $C$. arcticum has, although there has been an increase in Thalassiosira spp., but with no appreciable seasonal changes. The contribution that Thalassiosira spp. makes on the winter PCI value has declined.

Dinoflagellates, such as Ceratium arcticum, have evolved to exploit nutrient-depleted, well-stratified conditions (Holligan 1987). It is unlikely that the increase in C. arcticum is due to eutrophication, as nutrients in the area have varied little over the past $20 \mathrm{yr}$ (P. Pepin, Department of fisheries and oceans; DFO, pers. comm.), and the natural transport of nutrients seasonally onto the Banks would overwhelm any effect of eutrophication (Pepin \& Paranjape 1996). Therefore the increase in the PCI as well as C. arcticum is likely to be attributable to other factors. The ocean climate of the NW Atlantic is driven by thermohaline mechanisms, and these have an effect on large-scale processes such as the Labrador Current. Changes in the intensity of the Labrador Current have altered the annual structure of haline stratification. Work by Craig et al. (2001, 2002) indicates a change in haline stratification on the inner Newfoundland Shelf, with an index increasing significantly over the past decade. This is because surface waters throughout the 1990s have been fresher in the study area (ICES 2001), creating more persistent stratification. It is likely that this haline stratification plays an important part in C. arcticum abundance through a delay in the breakdown or initiation of an earlier stratified layer, although the exact mechanisms are not known. Haline stratification is known to stimulate phytoplankton blooms in coastal environments, even during winter months (Raymont 1963, Kimmerer 2002). The massive abundance of C. arcticum in 1996 (Fig. 3), where it contributed almost $47 \%$ of the total recorded phytoplankton community, corresponded to the freshest Labrador seawater event on record (Dickson \& Turrell 2000). SST in the area has fluctuated during the period 1960 to 2000, as can be seen from records of St. John's Harbour (DFO 1999). High temperatures were recorded in the 1960s, and declined towards the 1990s (with a minimum during the early 1990s). The exception to this was in 1996, when the 'flip' in the NAO resulted in temperatures well above normal in the area. Although the high NAO value, high temperature and high $C$. arcticum values could suggest a possible linkage, marked changes in the phytoplankton community were apparent from 1991, and SSTs have varied considerably between high and low values over the last decade. In addition, C. arcticum, as an arctic species, is present only in waters below $15^{\circ} \mathrm{C}$ (Dodge \& Marshall 1994).

A remaining point to address is how Ceratium arcticum has been able to bloom and flourish successfully during winter months over the last decade. It is possible that $C$. arcticum is adapted to flourishing under low-light conditions. For example, the sister species of $C$. arcticum, C. longipes, which is a cold water form, has a rate of photosynthesis over 20 times as great as the more cosmopolitan species C. fusus (Dodge \& Marshall 1994). The increased stratification of the water in the Grand Banks area could suggest reduced turbidity, allowing increased light exposure to marine organisms (IPCC 2001), which is utilised more efficiently by C. arcticum.

The Grand Banks has undergone wide-scale, identifiable changes in the marine ecosystem over the last decade, with the fisheries collapse the best documented. Although this has been attributed to anthropogenic influences (overfishing), not all research corroborates this theory. The changes noted in capelin ecology and distribution, forage fish for cod, as well as arctic-boreal zooplankton have been attributed to hydro-climatic variations (DFO 2000a, Johns et al. 2001). It is likely that shifts in the phytoplankton community of the Grand Banks area, due to an increase in stratification and changing hydro-climatic conditions, has had an additional affect on higher trophic levels.

Acknowledgements. We thank J. Craig, G. Lilly and P. Pepin (DFO) for their insightful comments. The CPR survey is supported by a funding consortium comprising agencies from Canada, France, Ireland, The Netherlands, Portugal, the UK and the USA. The survey depends on the voluntary co-operation of owners, masters and crews of merchant vessels which tow the CPRs on regular routes, playing an important part in monitoring macro-scale ecosystems and global change. We also wish to thank the CPR survey team past and present. 


\section{LITERATURE CITED}

Backhaus JO, Wehde H, Hegseth EN, Kämpf J (1999) 'Phytoconvection': the role of oceanic convection in primary production. Mar Ecol Prog Ser 189:77-92

Carscadden JE, Frank KT, Leggett WC (2001) Ecosystem changes and the effects on capelin (Mallotus villosus), a major forage species. Can J Fish Aquat Sci 58:73-85

Colebrook JM (1975) The Continuous Plankton Recorder survey: automatic data processing methods. Bull Mar Ecol 8: 123-142

Craig JDC, Colbourne EB (2002) Trends in stratification on the inner Newfoundland Shelf. Can Stock Assess Sec Res Doc no. 2002/071, Fisheries and Oceans Science, Ottawa

Craig JDC, Colbourne EB, Maillet GL (2001) Preliminary studies of density, stratification and fluorescence on the Newfoundland Shelf. Can Stock Assess Sec Res Doc no. 2001/085, Fisheries and Oceans Sciences, Ottawa

DFO (1999) 1997 State of the ocean: Northwest Atlantic. DFO Science Stock Status Report no. G0-01 Fisheries and Oceans Sciences, Ottawa

DFO (2000a) Capelin in Subarea $2+$ Div. 3KL. DFO Science Stock Status Report no. B2-02, Fisheries and Oceans Sciences, Ottawa

DFO (2000b) State of phytoplankton, zooplankton and krill on the Scotian Shelf in 1998. DFO Science Stock Status Report. no. G3-02, Fisheries and Oceans Sciences, Ottawa

Dickson RR, Turrell WR (2000) The NAO: the dominant atmospheric process affecting variability in home, middle and distant waters of European salmon. In: Mills D (ed) The ocean life of Atlantic salmon: environmental and biological factors influencing survival. Fishing News Books, London, p 92-115

Dodge JD, Marshall HG (1994) Biogeographic analysis of the armored planktonic dinoflagellate Ceratium in the North Atlantic and adjacent seas. J Phycol 30:905-922

Hays GC, Lindley JA (1994) Estimating chlorophyll a abundance from the ' $\mathrm{PCI}$ ' recorded by the Continuous Plankton Recorder survey: validation with simultaneous fluorometry. J Plankton Res 16:23-34

Holligan PM (1987) Physical environment of exceptional phytoplankton blooms in the Northeast Atlantic. In: Parker M, Tett P (eds) Rapport et process-verbaux des reunions: Commision Internationale l'Exploration de la mer Mediterranee, Vol. 187. ICES, Paris, p 9-18

Hutchings JA (1996) Spatial and temporal variation in the density of northern cod and review of hypotheses for the stock's collapse. Can J Fish Aquat Sci 53:943-962

ICES (International Council for Exploration of the Seas) (2001) Report of the Working Group on Oceanic Hydrography, no. CM 2001/C: 06. In: Holliday P, Turrell B (eds) The annual ICES climate status summary 2001/2002. ICES, Copenhagen, p 73-77

IPCC (Intergovernmental Panel on Climate Change) (2001) Climate change 2001: the scientific basis. In: Houghton JT, Ding Y, Griggs DJ, Noguer M, van der Linden PJ, Dai X, Maskell $\mathrm{K}$, Johnson CA (eds) Contribution of working Group I to the third assessment report of the intergovernmental panel on climate change. Cambridge University Press, Cambridge

John EH, Batten SD, Stevens DS, Walne AW, Jonas TJ, Hays GC (2002) Continuous Plankton Records stand the test of

Editorial responsibility: Otto Kinne (Editor),

Oldendorf/Luhe, Germany time: evaluation of flow rates, clogging and the continuity of the CPR time-series. J Plankton Res 24:941-946

Johns DG, Edwards M, Batten SD (2001) Arctic boreal plankton species in the Northwest Atlantic. Can J Fish Aquat Sci 58:2121-2124

Kimmerer WJ (2002) Effects of freshwater flow on abundance of estuarine organisms: physical effects or trophic linkages. Mar Ecol Prog Ser 243:39-55

Labry C, Herbland A, Delmas D, Laborde P, Lazure P, Froidefond JM, Jegou AM, Sautour B (2001) Initiation of winter phytoplankton blooms within the Gironde plume waters in the Bay of Biscay. Mar Ecol Prog Ser 212:117-130

Lebour MV (1925) The dinoflagellates of Northern Seas. Marine Biological Association, Mayflower Press, Plymouth

Lilly GR (1994) Predation by Atlantic cod on capelin on the southern Labrador and Northeast Newfoundland shelves during a period of changing spatial distributions. In: Proc of the ICES Mar Sci Symp on Cod and Climate Change, 23-27 August 1993, Reykjavik. ICES, Copenhagen, p 600-611

Morgan MJ, Brodie WB, Kulka DW (2002) Was overexploitation the cause of the decline of the American plaice stock off Labrador and northeast Newfoundland? Fish Res 57:39-49

Nakashima BS (1994) The relationship between oceanographic conditions in the 1990s and changes in spawning behaviour, growth and early life history of capelin (Mallotus villosus). NAFO Sci Coun Stud 24:55-68

Okolodkov YB, Dodge JD (1996) Biodiversity and biogeography of planktonic dinoflagellates in the Arctic Ocean. J Exp Mar Biol Ecol 202:19-27

Pepin P, Paranjape M (1996) Summary of biological oceanographic variables in the Newfoundland region. DFO Atlantic Fisheries Research Document no. 96/2

Pickart RS, McKee TK, Torres DJ, Harrington SA (1999) Mean structure and interannual variability of the slopewater system south of Newfoundland. J Phys Oceanogr 29: $2541-2558$

Prasad KS, Haedrich RL (1994) Satellite-derived primary production estimates from the Grand Banks: comparison to other ocean regimes. Cont Shelf Res 14:1677-1687

Raymont JEG (1963) Plankton and productivity in the oceans. Pergamon Press, London

Robinson GA (1970) Continuous Plankton Records: variation in the seasonal cycle of phytoplankton in the North Atlantic. Bull Mar Ecol 6:333-345

Robinson GA, Hiby AR (1978) The Continuous Plankton Recorder survey. In: Sournia A (ed) Phytoplankton manual. UNESCO, Paris, p 59-63

Sameoto DD (2001) Decadal changes in phytoplankton colour index and selected calanoid copepods in continuous plankton recorder data from the Scotian Shelf. Can J Fish Aquat Sci 58:749-761

Smayda TJ (1958) Biogeographical studies of marine phytoplankton. Oikos 9:159-191

Venables WN, Ripley BD (2002) Statistics and computing. Modern applied statistics with S. Springer-Verlag, New York

Warner AJ, Hays GC (1994) Sampling by the Continuous Plankton Recorder survey. Prog Oceanogr 34:237-256

Williams R, Lindley JA (1980) Plankton of the Fladen Ground during FLEX 76 I. Spring development of the plankton community. Mar Biol 57:73-78

Submitted: January 31, 2003; Accepted: October 11, 2003

Proofs received from author(s): December 12, 2003 